\title{
Forage yield and white-tailed deer diets following live oak control
}

\author{
TIMOTHY E. FULBRIGHT AND ANDRES GARZA, JR.
}

\begin{abstract}
Live oak (Quercus virginiana Mill.) competes with herbaceous plants, but provides browse and mast for white-tailed deer (Odocoileus virginianus Zimmerman). We determined the effects of treating live oak with tebuthiuron on yield of herbaceous vegetation and white-tailed deer diets and nutritional indices. In 1982, 259 ha were aerially treated with $2.2 \mathrm{~kg} / \mathrm{ha}$ active ingredient of tebuthiuron pellets in parallel, alternating treated and untreated strips, each measuring $76 \mathrm{~m}$ wide. A second area was treated in 1984. We clipped herbage during June and November 1985-86 within exclosures in treated and untreated strips, and determined chemical and botanical composition of rumen contents and kidney fat index (KFI) from deer killed in the 1982 strip treatment area and a control (untreated) area. Grass yield was 2-4 times higher on treated than on untreated range. Forb yield was almost 5 times greater on range treated in 1982 than on untreated range, but yield on untreated range and areas treated in 1984 was similar. Deer sampled in the control area had consumed more forbs than those sampled in the herbicide-stripped area except in fall 1985. The KFI was greater for deer sampled in the control area in fall 1985 and greater for those sampled in the stripped area in fall 1986. Treatment with tebuthiuron in alternating strips increased forage yield for cattle and was apparently not detrimental to KFI of deer.
\end{abstract}

Key Words: Odocoileus virginianus, Quercus virginiana, tebuthiuron, herbicides, habitat, brush management, nutrition

A large increase in the abundance of woody plants occurred on rangelands in North America and other areas of the world during the last 50-300 years (Archer et al. 1988). Among the woody plants that increased in density in areas that were formerly grassland, savannah, or open woodland are various Quercus species such as Gambel's oak ( $Q$. gambelii Nutt.), blackjack oak ( $Q$. marilandica Muenchh.), post oak ( $Q$. stellata Wang.), and live oak ( $Q$. virginiana Mill.). Live oak occupies about 6.5 million ha of Texas rangeland. Dense stands $>20 \%$ canopy cover) of the plant dominate almost 740 thousand ha and reduce forage production for livestock because of competition between woody plants and herbaceous vegetation (Smith and Rechenthin 1964).

Mechanical, chemical, and pyric treatments have been used during the last $\mathbf{5 0}$ years to reduce live oak density and increase forage yield for cattle. Root plowing is the most effective mechanical method of controlling live oak (Scifres 1980), but it is expensive and reseeding is necessary after the treatment. Prescribed burning temporarily reduces height of live oak, but increases stem density (Springer et al. 1987). Live oak is not controlled with commonly used rates of phenoxy herbicides (Scifres 1980). Tebuthiuron is a soil-applied herbicide that effectively kills live oak (Meyer and Bovey 1980) and other oak species (Doerr and Guthery 1983, Scifres et al. 1987).

Live oak provides browse and mast for white-tailed deer (Odo-

Authors are associate professor and research associate, Caesar Kleberg Wildlife Research Institute, Box 218, Texas A\&I University, Kingsville 78363. Garza is currently field representative, Texas State Soil and Water Conservation Board, 104 Magnolia, Falfurrias, Texas 78355 .

Research was funded by the Caesar Kleberg Foundation for Wildlife Conservation. Authors thank S. Hopper for use of the study area and F. Guthery, C. DeYoung, E. Hellgren, and $R$. Bingham for reviewing early drafts of the manuscript. The cooperation and assistance of $\mathbf{R}$. Osburn is appreciated.

Manuscript accepted 16 October 1990. coileus virginianus Zimmerman). Ranchers in south Texas are reluctant to treat live oak with tebuthiuron because information on effects of treating live oak on forage yields is meager and effects on deer habitat are unknown. Our objectives were to determine the effects of tebuthiuron application in a live oak woodland on (1) yield of herbaceous vegetation and (2) plant composition of diets and selected indices of nutritional status of white-tailed deer.

\section{Study Area}

The study was conducted on the 4,856-ha Tepeguaje Ranch in southern Brooks County, Texas. Brooks County is in the Coastal Sand Plain of southern Texas (Diamond and Fulbright 1990). The region is a honey mesquite (Prosopis glandulosa Torr.)- live oakseacoast bluestem [ Schizachyrium scoparium var. littoralis (Nash) Gould] savannah. Canopy cover of live oak averaged $65 \%$ in the study area. Major grasses and forbs in the study area included common sandbur (Cenchrus incertus M.A. Curtis), fringed signal grass [Brachiaria ciliatissima (Buckl.) Chase], Texas bristlegrass grass (Setaria texana Emery), Texasgrass [Vaseyochloa multinervosa (Vasey) Hitchc.], American snoutbean [Rhynchosia americana (Mill.) Metz.], Mexican clover (Richardia sp.), Evolvulus sp., and wooly croton (Croton capitatus Michx.).

Soil of the study area is Falfurrias fine sand, a mixed, hyperthermic Typic Ustipsamment (Turner 1982) with low waterholding capacity (F. Saenz, Soil Conservation Service, Falfurrias, Texas, pers. commun.) Average annual precipitation $(61 \mathrm{~cm})$ is bimodal with $50 \%$ falling in May, June, September, and October. Rainfall during the study was above average (Fig. 1). The mean

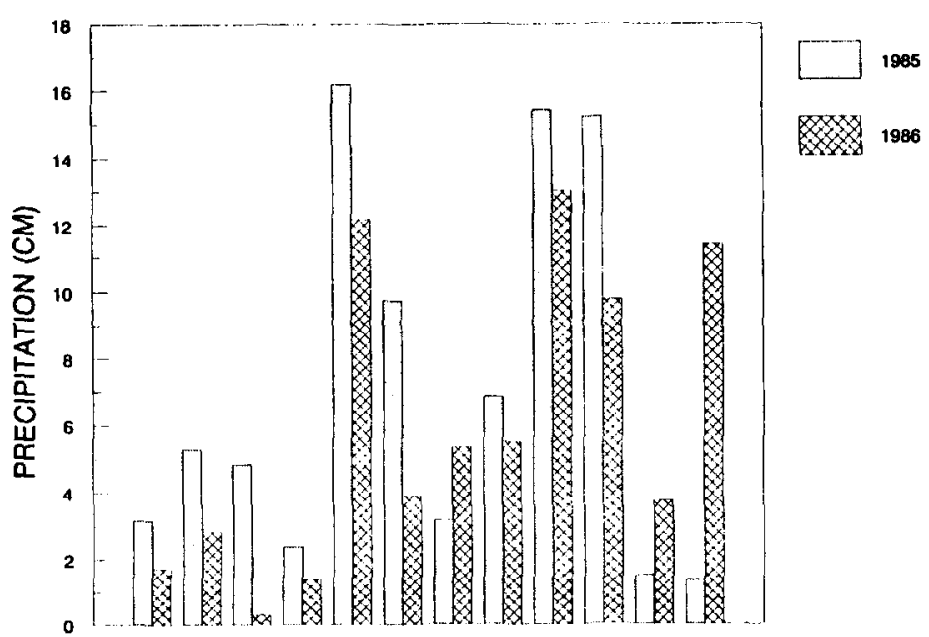

JAN FEB MAR ARR MAY JUN JUL AUG SEP OCT NOV DEC

Fig. 1. Monthly precipitation (cm) at Falfurias, Brooks County, Texas. 1985-1986 (NOAA 1985, 1986).

annual temperature is $22^{\circ} \mathrm{C}$ and the growing season ranges from 250 to 365 days.

The study area was grazed continuously by cattle at 8 ha/AU. White-tailed deer densities averaged 5 ha/deer from 1984 to 1987 according to spot-light counts (R. Howard, wildlife biologist, San Tomas Hunting Camp, Encino, Texas). 
Table 1. Standing crop $(\mathrm{kg} / \mathrm{ha})(n=12)$ of selected and total grasses, grass-like plants, and forbs on untreated strips of live oak woodland (Untr) and strips of live oak woodland treated with $2.24 \mathrm{~kg} / \mathrm{ha}$ active ingredient tebuthiuron pellets in November, 1982 (Treated), Brooks County, Texas, $1985-1986$.

\begin{tabular}{|c|c|c|c|c|c|c|c|c|}
\hline \multirow[b]{3}{*}{ Plant class species } & \multicolumn{4}{|c|}{1985} & \multicolumn{4}{|c|}{1986} \\
\hline & \multicolumn{2}{|c|}{ June } & \multicolumn{2}{|c|}{ November } & \multicolumn{2}{|c|}{ June } & \multicolumn{2}{|c|}{ November } \\
\hline & Untr & Treated & Untr & Treated & Untr & Treated & Untr & Treated \\
\hline Grasses & 628 & $2,088 * *$ & 571 & $1,303 * *$ & 398 & $1,727 * *$ & 458 & $1,395^{* *}$ \\
\hline Common sandbur & 27 & 229 & 5 & $108 * * *$ & 17 & $190^{* *}$ & 13 & $83^{*}$ \\
\hline Fringed signal grass & 0 & $724^{*}$ & 0 & $278 *$ & 3 & 248 & 10 & 50 \\
\hline \multicolumn{9}{|l|}{ Texas } \\
\hline bristlegrass & 171 & 154 & 96 & 217 & 45 & 197 & 58 & 104 \\
\hline Texasgrass & 358 & 231 & 419 & 274 & 277 & 358 & 311 & 605 \\
\hline Grasslikes & 0 & 28 & 0 & 0 & 1 & 42 & 0 & 17 \\
\hline Forbs & 66 & 295 & 14 & $63^{* * *}$ & 29 & 117 & 21 & $120^{* * *}$ \\
\hline American snoutbean & 8 & 14 & 2 & 5 & 3 & 27 & 1 & $13^{* * *}$ \\
\hline Evolvulus sp. & 6 & 3 & 0 & 3 & 0 & 10 & 4 & $21 * * *$ \\
\hline Mexican clover & 29 & 109 & 4 & 27 & 8 & 13 & 0 & 36 \\
\hline Wooly croton & 2 & 96 & $\mathbf{0}$ & 4 & 0 & 28 & 0 & 29 \\
\hline
\end{tabular}

*,**Means for a species within a sampling date significantly different at $P<0.05$ or $P<0.01$, respectively. Means within a sampling date were analyzed separately using t-tests if the sampling date $X$ treatment interaction was significant $(P \leq 0.05)$.

$* * *$ Treatment main effect for a plant species significantly different at $P \leq 0.05$. Data for 1985 and 1986 were analyzed separately.

\section{Methods}

\section{Grass and Forb Yield}

In November, 1982,259 ha of live oak-dominated woodland were aerially treated with $2.24 \mathrm{~kg}$ active ingredient $/ \mathrm{ha}$ of $20 \%$ tebuthiuron pellets in parallel 76 -m-wide strips alternating with 76-m-wide untreated strips. An adjacent 238 ha were treated in April 1984 at the same rate in parallel $51-\mathrm{m}$-wide treated strips alternating with $99-\mathrm{m}$-wide untreated strips. Mortality of live oaks in the treated strips was $100 \%$. In spring 1985,4 randomly placed square $18-\mathrm{m}^{2}$ exclosures were constructed to prevent grazing by cattle in each of 3 randomly selected strips treated in 1982. Four exclosures were also constructed in an untreated strip adjacent to each treated strip ( $n=12$ exclosures in both treated strips and untreated strips). Exclosures were similarly constructed in strips treated in 1984 and in adjacent untreated strips. During June and November 1985,2 randomly placed $0.5-\mathrm{m}^{2}$ plots were clipped to ground level in each exclosure. Exclosures were rerandomized during January 1986 and 2 exclosures were placed in each of 6 randomly selected treated strips and in adjacent untreated strips in the 1982 and 1984 treatments. Two randomly placed $0.5-\mathrm{m}^{2}$ plots were clipped to ground level in each exclosure in June and November 1986. For all samples, plant material was sorted by species, oven-dried to a constant weight at $55^{\circ} \mathrm{C}$, and weighed to the nearest $0.1 \mathrm{~g}$.
Data were analyzed with analysis of variance using a completeblock design (Gill 1981). Each block in the analysis was a pair of exclosures: 1 within a treated strip and 1 within an adjacent untreated strip ( $n=12$ pairs). Thus, the treatments were not randomized within blocks. A complete-block design is appropriate when treatments are not randomized within blocks but results should be cautiously interpreted (Gill 1981: 198-203). Years were analyzed separately because different exclosures were used. When the sampling date by treatment interaction was significant $(P \leq 0.05)$, sampling dates were analyzed separately with paired $t$-tests.

\section{Deer Diet Composition and Nutritional Indices}

A control (untreated) area of live oak woodland similar in size and vegetation to the area of treated and untreated strips was selected. The closest edge of the control area was $3 \mathrm{~km}$ from the edge of the treated area. Hyde (1987) reported that average home range sizes for females on continuously-grazed rangeland adjacent to our study area ranged from 105 ha between 1 November 1985 and 15 January 1986 to 581 ha between 16 January and 30 June 1986. Thus, samples between sites probably were independent.

Four to 5 female white-tailed deer were shot in May 1985 and November 1985 and 1986 in the area treated in 1982 and the same number were shot in the control area. Deer were eviscerated and weighed. Kidney fat indices (KFI) were determined (Riney 1955).

Table 2. Standing erop $(\mathrm{kg} / \mathrm{ha})(n=12)$ of selected and total grasses, grass-like plants, and forbs on untreated strips of live oak woodland (Untr) and strips of live oak woodland treated with $2.24 \mathrm{~kg} / \mathrm{ha}$ active ingredient tebuthiuron pellets in April, 1984 (Treated), Brooks County, Texas, $1985-1986$.

\begin{tabular}{|c|c|c|c|c|c|c|c|c|}
\hline \multirow[b]{3}{*}{ Plant class species } & \multicolumn{4}{|c|}{1985} & \multicolumn{4}{|c|}{1986} \\
\hline & \multicolumn{2}{|c|}{ June } & \multicolumn{2}{|c|}{ November } & \multicolumn{2}{|c|}{ June } & \multicolumn{2}{|c|}{ November } \\
\hline & Untr & Treated & Untr & Treated & Untr & Treated & Untr & Treated \\
\hline Grasses & 462 & $1,885 * *$ & 453 & $1,175 * *$ & 491 & 2,061 & 510 & $1,686 * * *$ \\
\hline Common sandbur & 8 & 0 & 0 & 2 & 8 & 97 & 9 & $144 * * *$ \\
\hline Fringed signalgrass & 40 & 75 & 14 & 68 & 3 & 92 & 0 & 208 \\
\hline \multicolumn{9}{|l|}{ Texas } \\
\hline bristlegrass & 35 & 17 & 73 & 148 & 90 & 632 & 67 & $294 * * *$ \\
\hline Texasgrass & 278 & 661 & 291 & $825 * * *$ & 277 & 422 & 373 & 818 \\
\hline Grasslikes & 4 & 35 & 0 & 10 & 0 & $31^{m *}$ & 0 & 0 \\
\hline Forbs & 34 & 23 & 9 & 2 & 34 & 62 & 11 & 34 \\
\hline American snoutbean & 12 & $1 * *$ & 2 & 1 & 3 & 20 & 2 & 8 \\
\hline Evolvulus sp. & 0 & 0 & 0 & 0 & 1 & 11 & 2 & 1 \\
\hline Mexican clover & 0 & $\mathbf{0}$ & 0 & 0 & 3 & 0 & 0 & 0 \\
\hline Wooly croton & 2 & $\mathbf{0}$ & 0 & 0 & 3 & 5 & 2 & 0 \\
\hline
\end{tabular}

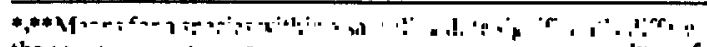
the s.

$P<0.05$ or $P<0.01$, respectively. Means within a sampling date were analyzed separately using t-tests if : $\leq 0.05$. Data for 1985 and 1986 were analyzed separately. 
Rumen contents of each deer were thoroughly mixed and 2 samples were taken. One rumen sample $(250-300 \mathrm{ml})$ was preserved in $100 \%$ ethanol and sent to the Wildlife Habitat Laboratory at Washington State University for microhistological analysis of botanical composition. Deer were not collected in May 1986 at the request of the landowner, so we collected fresh fecal samples ( $n=8$ fecal groups on the control area and 10 on the treated area) in June 1986 for determination of diet composition. Microhistological examination of samples followed procedures outlined by Nelson and Davitt (undated) and Davitt and Nelson (1980). For each sample, 15-30 fields each on 2 microscopic slides were examined. The number of fields examined depended on the number of samples taken on each collection date and totaled 300 fields per collection date and treatment. Relative cover of each plant species in the diet was calculated (Nelson and Davitt, undated).

A second rumen and a fecal sample (5-10 g) from each deer was frozen. Later, these samples were dried at $40^{\circ} \mathrm{C}$ and ground in a Wiley mill to pass through a $1-\mathrm{mm}$ screen. Dry matter and organic matter contents were determined following AOAC (1980) procedures. Crude protein $(\mathrm{CP})(\% \mathrm{~N} \times 6.25)$ was determined by the micro-Kjehldahl procedure (AOAC 1980) and is reported on an organic-matter basis. Atomic absorption spectrophotometry was used to determine calcium $(\mathrm{Ca})$ levels and phosphorus $(\mathrm{P})$ content was determined colorimetrically (Parkinson and Allen 1975). Fecal acid pepsin disappearance was used to compare energy intake (Mubanga et al. 1985). Samples were analyzed in duplicate and $\mathrm{Ca}$ and $\mathrm{P}$ contents are reported on a dry-matter basis.

Treatments were not replicated because of the expense of the treatments (herbicide application cost $\$ 106.25 /$ ha) and because additional study areas were unavailable. Thus, site effects are confounded with treatment effects, and inferences about deer diets and nutritional indices pertain to the sites and not to treatment effects. Inferential statistics may be used to compare responses between sites with unreplicated treatments if inferences are made only about sites and not about treatment effects (Guthery 1987).

Data were analyzed with analysis of variance using a completely random design (Snedecor and Cochran 1967). Collection date and treatment were main effects in the analysis. When the interaction of collection date and treatment was significant, collection dates were analyzed separately using $t$-tests. Fecal sample data collected in June 1986 were analyzed separately from rumen analysis data. Percentage data were arcsin transformed before analysis. Means (Table 3) are untransformed values.

\section{Results and Discussion}

\section{Standing Crop of Herbaceous Vegetation}

Standing crop of grasses was greater $(P \leq 0.05)$ on strips treated in 1982 and in 1984 than on untreated strips on all sampling dates (Tables 1 and 2). Our results are similar to those of other studies in different vegetation types that showed increases in grass production following tebuthiuron treatment (Doerr and Guthery 1983, Biondini et al. 1986, Scifres et al. 1987, DeFazio et al. 1988).

Forb standing crop was similar $(P>0.05)$ in strips treated in 1984 and in untreated strips in 1985 and 1986 (Table 1). In strips treated in 1982 , forb standing crop averaged $4 \frac{1}{2}$ times greater $(P=0.026)$ in treated than in untreated strips in 1985 and almost 5 times higher $(P=0.038)$ in 1986 (Table 1). Mexican clover was the most abundant forb in strips treated in 1982 and in untreated strips during 1985. In 1986, American snoutbean and Evolvulus sp. were among the forb species with greater $(P<0.05)$ standing crops in the treated strips than in the untreated strips.

High rates of tebuthiuron similar to those used in our study generally cause an initial reduction in forb standing crop. Forb standing crops were reduced the first 3 growing seasons after tebuthiuron treatment $(2.2 \mathrm{~kg} / \mathrm{ha})$ of rangeland dominated by post
Table 3. Mean ( $n=4-5$ ) body weight $(\mathrm{kg})$, kidney fat index (KFI), fecal acid pepsin disappearance $(\%)$, and rumen and fecal crude protein (\%), phosphorus (\%), and calcium (\%) of white-tailed deer in live-oak dominated rangeland untreated (Cont) or treated during 1982 with tebuthiuron in alternating treated and untreated strips (Stri), Brooks County, Texas, 1985-1986.

\begin{tabular}{|c|c|c|c|c|c|c|}
\hline \multirow[b]{3}{*}{ Nutritional index } & \multicolumn{6}{|c|}{ Sampling date and treatment } \\
\hline & \multicolumn{2}{|c|}{ Spring 1985} & \multicolumn{2}{|c|}{ Fall 1985} & \multicolumn{2}{|c|}{ Fall 1986} \\
\hline & Cont & Stri & Cont & Stri & Cont & Stri \\
\hline Body weight (kg) & 31.0 & 29.2 & 28.6 & 30.3 & 29.0 & 30.1 \\
\hline KFI $(\%)$ & 50.8 & 53.3 & 32.8 & $20.7^{*}$ & 10.2 & $30.2^{*}$ \\
\hline \multicolumn{7}{|l|}{ Crude protein $(\%)$} \\
\hline Rumen & 21.9 & 24.8 & 22.3 & $17.3^{*}$ & 22.7 & 22.3 \\
\hline Feces & 18.5 & 17.5 & 12.4 & 12.1 & 20.4 & 21.0 \\
\hline \multicolumn{7}{|l|}{ Phosphorus (\%) } \\
\hline Rumen & 2.3 & 2.1 & 1.9 & 1.5 & 1.7 & 1.7 \\
\hline Feces & 0.5 & 0.4 & 0.6 & 0.4 & 0.3 & 0.3 \\
\hline \multicolumn{7}{|l|}{ Calcium (\%) } \\
\hline Rumen & 3.7 & 2.3 & 1.0 & 1.4 & 1.6 & 1.3 \\
\hline Feces & 7.2 & 5.0 & 2.8 & 2.8 & 2.5 & $1.3^{* * *}$ \\
\hline \multicolumn{7}{|l|}{$\begin{array}{l}\text { Fecal acid pepsin } \\
\text { disappearance }\end{array}$} \\
\hline$(\%)$ & 28.1 & 33.9 & 22.7 & 25.1 & 43.7 & 42.7 \\
\hline
\end{tabular}

'**:Means for a species within a sampling date significantly different at $P<0.05$ or $P<0.01$, respectively. Means within a sampling date were analyzed separately using t-tests if the sampling date $\times$ treatment interaction was significant $(P \leq 0.05)$.

*** Treatment area main effect for nutritional index significantly different at $P \leq 0.05$.

oak and blackjack oak (Scifres et al. 1987). However, forb standing crops were greater on pastures treated with tebuthiuron by the fourth year after treatment.

\section{White-tailed Deer Diets and Nutritional Indices}

Percent browse in deer diets was similar $(P>0.05)$ on the control and herbicide-stripped areas (Figs. 2-5). In spring 1985, browse comprised $42 \%$ of rumen samples in the control and $39 \%$ in the herbicide-stripped area. Browse comprised $<10 \%$ of the diet in fall

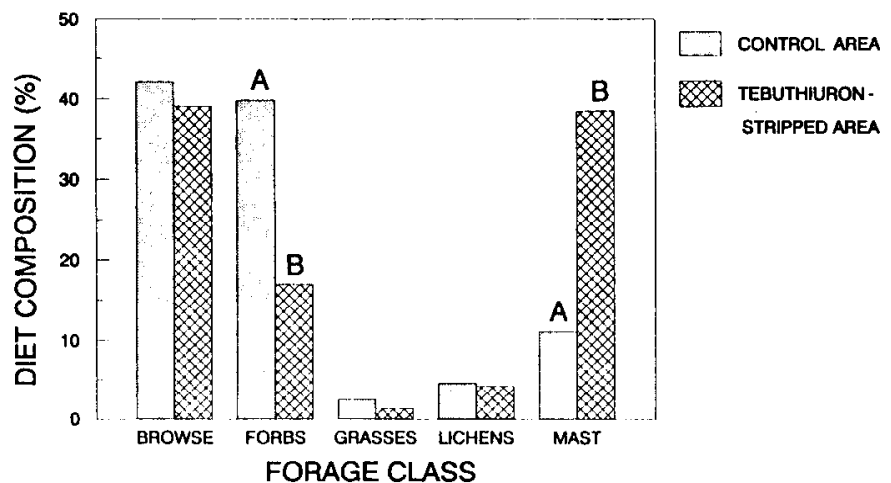

Fig. 2. Mean percentage of browse, forbs, grasses, and grass-like plants, lichens, and mast in white-tailed deer diets in live-oak dominated rangeland strip-treated with tebuthiuron and untreated (control) in the spring, 1985 according to microhistological analysis of rumen samples $(n=5)$. Means in a pair of bars associated with the same letter were similar $(P>0.05)$ according to $t-t e s t s$. Treatment area main effects were significant $(P=0.0057)$ for lichens and were not significant $(P>0.05)$ for browse and grasses and grasslikes.

1985 and 1986. Live oak comprised more than $70 \%$ of the browse consumed in all seasons. Other browse species eaten included common lantana (Lantana horrida H.B.K.), bluewood (Condalia obovata Hook.), and spiny hackberry (Celtis pallida Torr.).

Forb composition of the diet was greater $(P \leq 0.05)$ in the control area than in the herbicide-stripped area on all sampling dates except fall 1985 (Figs. 2-5). In the fall 1985, forbs comprised $49 \%$ of 


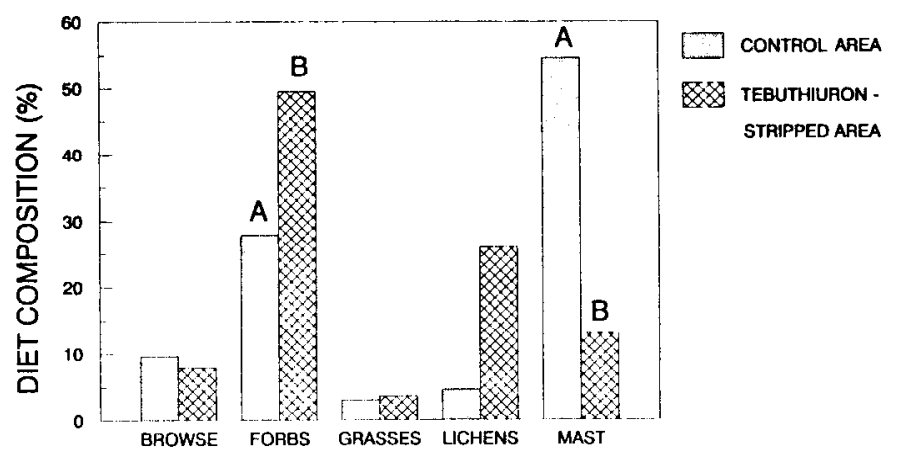

FORAGE CLASS

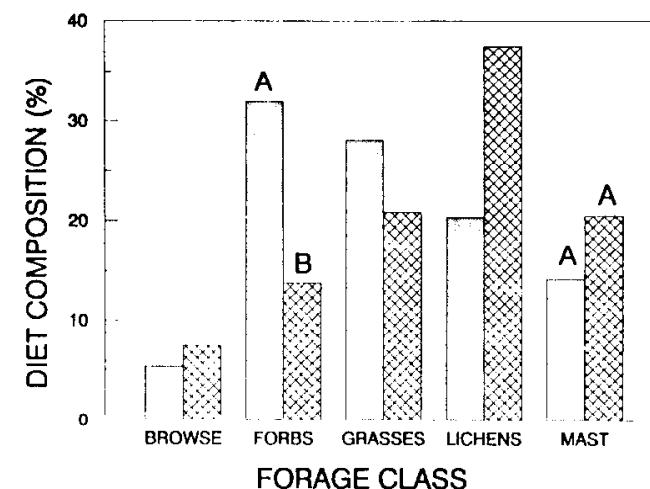

Fig. 5. Mean percentage of browse, forbs, grasses and grass-like plants, lichens, and mast (and seeds) in white-tailed deer diets in live-oak dominated rangeland strip-treated with tebuthiuron and untreated (control) in the fall, 1986 according to microhistological analysis of rumen samples $(n=5)$. Means in a pair of bars associated with the same letter were similar $(P>0.05)$ according to $t-t e s t s$. Treatment area main effects were significant $(P=0.0057)$ for lichens and were not significant $(P>0.05)$ for browse and grasses.

may have resulted in greater consumption.

Mast and forb seeds comprised $39 \%$ of diets on the herbicidestripped area compared to $11 \%$ in the control in spring 1985 (Fig. 2). In fall 1985 , mast and forb seeds comprised $55 \%$ of diets in the control area and only 13\% in the herbicide-stripped area (Fig. 3). The proportion of mast and forb seeds in diets was similar $(P>0.05)$ in the control and herbicide-stripped areas in spring and fall 1986 (Figs. 4 and 5). Mast consumed in spring 1985 was primarily acorns, honey mesquite pods, and tasajillo (Opuntia leptocaulis D.C.) fruits. Forb seeds were consumed in greater ( $P=$ $0.014)$ amounts on the herbicide-stripped than on the control area in spring 1985. In fall 1985 , live oak acorns comprised more (26\%) $(P=0.013)$ of deer diets on the control than on the herbicidestripped (5\%) area. Although we did not measure acorn yield, we observed that few acorns were produced in the fall 1986, and consequently acorns comprised only 1 and $6 \%$ of diets on the control and herbicide-stripped areas, respectively. Grasses and grass-like plants and lichens composed a greater $(P \leq 0.05)$ portion of deer diets in fall 1986 than in the previous fall possibly because of the low availability of acorns in fall 1986.

Deer body weights were similar $(P>0.05)$ in the control and herbicide-stripped areas (Table 3). The KFI was greater $(P=0.042)$ in the control than in the herbicide-stripped area in fall 1985, and greater $(P=0.015)$ in the herbicide-stripped area than in the control in fall 1986.

Crude protein of rumen contents was similar $(P>0.05)$ in the control and herbicide-stripped areas in spring 1985 and fall 1986, and was greater $(P=0.039)$ in the control in fall 1985 (Table 3). Crude protein content of feces, Ca content of rumens, $P$ content of rumens and feces, and fecal acid pepsin disappearance were similar $(P>0.05)$ between sites on all sampling dates. Averaged across sampling dates, Ca content of feces was greater $(P=0.0051)$ in the control area than in the herbicide-stripped area. Karn and Hofmann (1990) found that fecal Ca of grazing cattle and Ca content of simulated diets were highly correlated.

\section{Conclusions}

Treating live-oak dominated rangeland with tebuthiuron pellets at $2.2 \mathrm{~kg} / \mathrm{ha}$ increased grass yield and may increase grazing capacity for cattle. Tebuthiuron application did not reduce forb yield during the first growing season after treatment, partly because forb yield under the dense live-oak canopy was negligible before treat- 
ment. Removal of the live-oak canopy with tebuthiuron resulted in a substantial increase in forb yield 3 and 4 years posttreatment. Although forb yield was increased, certain of the most abundant forbs (e.g., Evolvulus, Mexican clover) in treated strips were unimportant in deer diets.

Differences in diet composition, KFI, rumen CP, and fecal Ca existed between deer in the area treated with tebuthiuron and deer in the control area. However, our results did not indicate that deer nutritional status was adversely impacted in the herbicide-stripped area because (1) differences in KFI between the herbicide-stripped and control areas were inconsistent (e.g., higher KFI in the control area in fall 1985 and higher KFI in the herbicide-stripped area in fall 1986) and (2) mean KFI values of deer in the treated area equaled or exceeded mean KFI values reported by Kie et al. (1983) for an average-density herd in south Texas $(20.8 \%$ in November and $16.0 \%$ in May). Inferences based on our results should be approached cautiously because (1) site effects were confounded with treatment effects because the experiment was not replicated, (2) untreated strips of live oak were present in the herbicidestripped area, and (3) deer had access to untreated live-oak dominated rangeland surrounding the 497-ha treated area; results may have differed if deer were confined to the area.

\section{Literature Cited}

AOAC. 1980. Official methods of analysis, 13th ed. Assoc. Official Anal. Chem., Washington, D.C.

Archer, S., C. Scifres, C.R. Bassham, and R. Maggio. 1988. Autogenic succession in a subtropical savanna: conversion of grassland to thorn woodland. Ecol. Monogr. 58:11-127.

Biodini, M., R.D. Pettit, and V. Jones. 1986. Nutritive value of forages on sandy soils as affected by tebuthiuron. J. Range Manage. 39:396-399.

Davitt, B.B., and J.R. Nelson. 1980. A method of preparing plant epidermal tissue for use in fecal analysis. Circ. 0628, Coll. of Agr. Res. Center, Washington State Univ.

DeFazio, J.T., Jr., A.E. Stone, and R.J. Warren. 1988. Effects of tebuthiuron site preparation on white-tailed deer habitat. Wildl. Soc. Bull. 16:12-18.

Diamond, D.D., and T.E. Fulbright. 1990. Contemporary plant communities of upland grasslands of the Coastal Sand Plain, Texas. Southwestern Natur. 35:385-392

Doerr, T.B., and F.S. Guthery. 1983. Effects of tebuthiuron on lesser prairie-chicken habitat and foods. J. Wildl. Manage. 47:1138-1142.

Gill, J.L. 1981. Design and analysis of experiments in the animal and medical sciences, vol. 2. Iowa State Univ. Press, Ames.

Guthery, F.S. 1987. Guidelines for preparing and reviewing manuscripts based on field experiments with unreplicated treatments. Wildl. Soc. Bull. 15:306.
Halls, L.K., ed. 1977. Southern fruit-producing woody plants used by wildlife. USDA, Forest Serv. Gen. Tech. Rep. SO-16.

Hyde, K.J. 1987. Effects of short duration grazing on white-tailed deer. M.S. Thesis, Texas A\&I Univ., Kingsville.

Karn, J.F., and L. Hofmann. 1990. Relationships between pasture forage components and fecal chemical composition. J. Range Manage. 43:320-325.

Kie, J.G., M. White, and D.L. Drawe. 1983. Condition parameters of white-tailed deer in Texas. J. Wildl. Manage. 47:583-594.

Mubanga, G., J.L. Holechek, R. Valdez, and S.D. Schemnitz. 1985. Relationships between diet and fecal nutritive quality in mule deer. Southwestern Natur. 30:573-578.

Meyer, R.E., and R.W. Bovey. 1980. Control of live oak (Quercus virginiana) and understory vegetation with soil-applied herbicides. Weed Sci. 28:51-58.

Nelson, J.R., and B.B. Davitt. Undated. Food habits information in wildlife habitat management, a comparison of methods and a description of the fecal analysis technique. Wildlife Habitat Management Services, Dep. of Forest. and Range Manage., Washington State Univ., Pullman, Washington.

NOAA. 1985. Climatological data annual summary, Texas. Vol. 90. National Oceanic and Atmospheric Administration, National Climatic Data Center, Asheville, N.C.

NOAA. 1986. Climatological data annual summary, Texas. Vol. 91 National Oceanic and Atmospheric Administration, National Climatic Data Center, Asheville, N.C.

Parkinson, J.A., and S.E. Allen. 1975. A wet oxidation procedure suitable for the determination of nitrogen and mineral nutrients in biological material. Comm. Soil Sci. and Plant Anal. 6:1-11.

Riney, T. 1955. Evaluating condition of free-ranging red deer (Cervus elaphus), with special reference to New Zealand. New Zealand J. Sci. Tech. 36:429-463.

Robbins, C.T. 1987. Digestibility of an arboreal lichen by mule deer. J. Range Manage. 40:491-492.

Scifres, C.J. 1980. Brush management. Texas A\&M Univ. Press, College Sta., Texas.

Scifres, C.J., J.W. Stuth, and B.H. Koerth. 1987. Improvement of oakdominated rangeland with tebuthiuron and prescribed burning. Texas Agr. Exp. Sta., Texas A\&M Univ., College Sta., Texas. B-1567.

Smith, H.N., and C.A. Rechenthin. 1964. Grassland restoration- the Texas brush problem. USDA, Soil Conserv. Serv., Fort Worth, Texas.

Snedecor, G.W., and W.G. Cochran. 1967. Statistical methods, 6th edition. Iowa State Univ. Press, Ames.

Springer, M.D., T.E. Fulbright, and S.L. Beasom. 1987. Long-term response of live oak thickets to prescribed burning. Texas J. Sci. 38:89-95.

Turner, A.J. 1982. Soil survey of Willacy County, Texas. USDA, SCS, U.S. Gov. Printing Office, Washington, D.C. 